NBER WORKING PAPER SERIES

\title{
AN ANALYSIS OF THE IMPACT OF AFFIRMATIVE ACTION PROGRAMS ON SELF-EMPLOYMENT IN THE CONSTRUCTION INDUSTRY
}

\author{
David G. Blanchflower \\ Jon Wainwright \\ Working Paper 11793 \\ http://www.nber.org/papers/w11793
NATIONAL BUREAU OF ECONOMIC RESEARCH 1050 Massachusetts Avenue
Cambridge, MA 02138 \\ November 2005
}

We thank Barry Hirsch, Colette Holt, John Scott, Chris Snyder, Jon Skinner, Doug Staiger and Jonathan Zinman for helpful comments and suggestions. All errors are ours The views expressed herein are those of the author(s) and do not necessarily reflect the views of the National Bureau of Economic Research.

(O2005 by David G. Blanchflower and Jon Wainwright. All rights reserved. Short sections of text, not to exceed two paragraphs, may be quoted without explicit permission provided that full credit, including $\odot$ notice, is given to the source. 
An Analysis of the Impact of Affirmative Action Programs on Self-Employment in the Construction Industry

David G. Blanchflower and Jon Wainwright

NBER Working Paper No. 11793

November 2005

JEL No. J4

\begin{abstract}
$\underline{\text { ABSTRACT }}$
The main findings of this paper are that despite the existence of various affirmative action programs designed to improve the position of women and minorities in public construction, little has changed in the last twenty five years. We present evidence showing that where race conscious affirmative action programs exist they appear to generate significant improvements: when these programs are removed or replaced with race-neutral programs the utilization of minorities and women in public construction declines rapidly. We show that the programs have not helped minorities to become selfemployed or to raise their earnings over the period 1979-2004, using data from the Current Population Survey and the Census, but have improved the position of white females. There has been a growth in incorporated self-employment rates of white women in construction such that currently their rate is significantly higher than that of white men. The data are suggestive of the possibility that some of these companies are 'fronts' which are actually run by their white male spouses or sons to take advantage of the affirmative action programs.

David G. Blanchflower

Department of Economics

6106 Rockefeller Hall

Dartmouth College

Hanover, NH 03755-3514

and NBER

blanchflower@dartmouth.edu

Jon Wainwright

NERA Economic Consulting

jon.wainwright@nera.com
\end{abstract}




\section{Introduction}

Construction is an important sector. In 2003, over 8 million workers, or approximately six per cent of total employment in the United States, held a construction job. ${ }^{1}$ This is made up of 6.7 million wage and salary jobs and 1.6 million self-employed and unpaid family non-government jobs. The construction industry accounts for a disproportionate share of union members and of the self-employed. The self-employment rate is over $30 \%$ for painters, carpenters, roofers and carpet, floor and tile installers. ${ }^{2}$ The construction industry, in 2003, accounted for $13.5 \%$ of all private sector union members and $16.7 \%$ of all of the unincorporated self-employed and approximately $14.9 \%$ of the incorporated self-employed. ${ }^{3}$ Employment of production workers in construction has increased over the last ten years, beginning at 4,113,000 in 1995 and rising to 5,332,000 in 2001. In 2004 employment of production workers averaged 5,300,000.

The construction industry accounts for about $9.7 \%$ of all private sector establishments. More than four out of five establishments in the industry employ fewer than 10 employees. There were about 698,000 construction establishments in the United States in 2002 using the 2002 NAICS; 216,000 were building construction contractors; 37,000 were heavy and civil engineering construction or highway contractors and 447,000 were specialty trade contractors. Building construction accounted for $24.9 \%$ of wage and salary employment in 2002; heavy and civil for $12.1 \%$ and specialty trades for $63.0 \%{ }^{4}$

According to the 2002 Economic Census Survey of Business Owners, of the 2,770,888 firms in construction, 2.4\% were owned by African Americans; $7.0 \%$ by Hispanics; $1.1 \%$ by American Indians or Alaskan natives; $1.4 \%$ by Asians and Pacific Islanders and $10.5 \%$ by women. The representation of minorities in particular among the ownership of firms in construction is well below their representation in the population as a whole. As a proportion of the population, according to the 2004/5 Statistical Abstract of the United States Table 13, in 2003 African Americans were 12.7\%; Hispanics 13.7\%; Asian/Pacific Islanders 4.3\%; American Indians/Alaskan Native $1.0 \%$ and two or more races $1.3 \% .^{5}$

\footnotetext{
${ }^{1}$ The main construction occupations in 2003 were, with number in thousands in parentheses, First-line supervisors (897); Brick masons (218); Carpenters (1,595); Carpet floor finishers (271); Cement masons (120); Construction laborers (1,151); Operating engineers (376); Drywall installers (205); Electricians (774); Painters (660); Pipe layers and plumbers (595); Roofers (233); Sheet metal workers (147); Helpers (114) and Inspectors (95). Source: Table 597 Statistical Abstract of the United States 2004-5 downloadable at www.census.gov/prod/2004pubs/04statab/labor.pdf

2 Source: www.bls.gov/oco/cg/pdf/cgs003.pdf

${ }^{3}$ Source: Statistical Abstract of the United States: 2004-2005, U.S. Census Bureau at www.census.gov/statab/www/ Table 586 and Union Membership and Coverage Database http://www.unionstats.com/ and own weighted estimates from the basic monthly files of the CPS for those aged 16-74.

4 Source: Statistical Abstract of the United States, 2004-5 Table 919

${ }^{5}$ Large disparities between blacks and whites, for example, are also found in relation to wealth (Kennickel, 2003); income (Bound and Freeman, 1992; Chandra, 2003; Heckman, Lyons and Todd, 2000 and Smith and Welch, 1989), educational achievement (Jencks and Phillips, 1998); out-of-wedlock childbearing (Ventura and Bachrach, 2000), health (see Chandra and Skinner, 2003), happiness (Blanchflower and Oswald, 2004) crime (Freeman, 2000) and even names (Fryer and Leavitt, 2003). The degree of residential segregation by race, though lower today than in the past is still high (Cutler, Glaeser and Vigdor, 1999).
} 
Ray Marshall (2000) has noted that there are several factors that make the construction industry especially important for minority development because it "provides opportunity for upward occupational mobility since workers commonly become managers and contractors". Glover (1977) notes that minorities have a long tradition in this industry as laborers, skilled workers and contractors and that it is possible to increase minority employment and income more effectively in construction than is the case with most other minority businesses.

There is a good deal of evidence that the under-representation of women and minorities in construction especially is due to widespread and pervasive discrimination that has changed little over time. Not only is the proportion of firms owned by African Americans especially relatively low, so also are their representation in the construction workforce in general and in selfemployment in particular. Where firms owned by minorities and women do exist in construction they are more likely than non-minority males to be in special trades rather than heavy and civil. They are also more likely to be sub-contractors than prime contractors. This does not appear to be because of a lack of an ability to expand to undertake these activities because it is well-known that small construction companies can expand rapidly as demand changes by hiring workers and renting equipment and making use of sub-contractors. A particular concern in construction is that it is hard for minority and women-owned firms to obtain capital, especially working capital, and this causes increased difficulties when bonds have to be posted. This is often made more difficult still when bonding firms are members of local construction associations. Also unions are pervasive in the sector and these unions have tended to be dominated by white males and have successfully controlled entry to craft jobs (Ashenfelter, 1972).

Construction projects especially in the public sector are frequently subject to competitive bidding procedures. There is some evidence to suggest that there is collusion among bidders. Typically governments award contracts for construction of highways and buildings through low-price sealed bid auctions. On the day of the auction sealed bids are publicly reported along with complete information about the bidder's identity and bids and the project is awarded to the lowest bidder. In a study of bidding in highway construction projects in Florida from 1981-1986 Gupta (2002) found that bid prices fall as the number of bidders increase. Gupta concluded that "collusion is commonplace in these markets," (p.22, 2002). Gupta (2001) used the same data on Florida and showed that bid prices were higher when repeated interaction among firms is present. "Recurring market contact among rivals can facilitate bid-rigging by discouraging the ring members to stray from collusive agreement" (p.466, 2001). Porter and Zona (1993) examined auctions in New York State highway construction projects in Long Island in the early 1980s and found evidence of bid-rigging. Firms had many opportunities to communicate with each other and some firms even submitted joint bids. They found evidence that several ring members bid on most jobs but one was a serious bidder and others submitted phoney higher bids. Porter and Zona argue that "the characteristics of this particular market tend to facilitate collusion" (p. 524, 1993). Feinsten et al (1985) studied North Carolina highway contracts and found that non-competitive bidding led to a clustering of bids in an attempt to influence engineer's estimates of the cost of future lettings.

Ingraham (2005) considered the possibility of bidder-official collusion in contracting and examined bidder data from New York City School Construction Authority auctions relating to 
school repair and construction for the period 1990-1997. In April 1993 a scandal relating to bid rigging became public and a number of prosecutions ensued: officials in the School Construction Authority colluded with contractors by operating a "magic-number" scheme. The corrupt official who acted as auctioneer would collude with a contractor and at the bid letting meeting would keep his bid until last and knowing the low bid would read aloud a false bid just below this price. Then after the bid opening the official would use White-Out to doctor the bid form. Ingraham's regression analysis suggested that two auctioneers (other than the auctioneer already convicted) may have been guilty of such magic-number cheating. Furthermore, an analysis of specific bidders yielded weak evidence that two additional bidders may have been guilty of magic number cheating. Such collusive arrangements between longstanding industry participants make it very hard for new firms, especially those owned by women and minorities, to enter and be successful.

The mechanism by which firms owned by minorities and women are likely excluded is that without the collusion and rotating of bids, so that prices are above the competitive level, firms would subcontract to minority owned businesses and use minority employees to lower costs and undercut the prices of their rivals. But, of course if the firms are dividing up the business, taking turns winning with higher than competitive bids, they have no need to compete by using low-cost inputs, so the benefits of competition are not only lost regarding the price that the public pays for the construction projects, but the benefits of competition for minorities are lost as well. The role of the bid letting organizations is probably mostly to tacitly, or in many localities even overtly, go along with or encourage the combination of banking and bonding discrimination on the financial side with the established construction firms' discriminatory subcontracting and hiring decisions. It appears to be a complex confluence of actions by non-minorities that keeps minority owned businesses from establishing themselves and surviving. The discrimination likely results from a combination of actions from bid letting organizations, bidding companies, banks, and bonding companies. The bid letting organizations go along and probably in some locales even encourage the discrimination, the bidding firms in the club do not have competitive incentives to hire lower-cost subcontractors and employees, the banks and other financiers and bonding companies discriminate so they do not qualify as bidders on the financial side whatever their business qualifications. So, collusion aids discrimination in subcontracting and in employment. ${ }^{6}$

Affirmative action programs in construction have been implemented in many jurisdictions to help overcome some of these problems. To prevent fraud, firms eligible for participation in the programs have to register and be approved before they can participate. In many jurisdictions the programs have been challenged in the courts on constitutional grounds and subsequently removed entirely or replaced in whole or part with much weaker programs that are "race and gender neutral” or their goals have been lowered. We document below that when such programs are removed any improvements that have been achieved seem to rapidly disappear. Jurisdictions continue to have difficulties in ensuring that firms that are fronted by minorities or women but are really owned by white males are not benefiting from these programs.

\footnotetext{
${ }^{6}$ We thank John Scott for helpful discussion on these points.
} 
In response to legal action and the threat of potential legal action the U.S. Department of Transportation (USDOT), which operates one of the most significant federal programs for affirmative action in construction, now allows its grant recipients to set annual goals for participation by minorities, women, and other disadvantaged businesses with either a race/gender conscious component, a race/gender neutral component, or both. Since the implementation of this policy beginning in FY2000, there has been a huge increase in the portion of grant recipients' goals that are approved to be met exclusively or predominantly through race/gender neutral means. These USDOT affirmative action programs are run under the auspices the Federal Transit Authority (FTA), the Federal Aviation Authority (FAA) and the biggest of them by the Federal Highways Administration (FHWA)

For example, of 201 FTA grant recipients we reviewed for FY2002, only 61 (30\%) had goals that were predominantly race/gender conscious. By contrast, 93 entities (46\%) had FY2002 DBE goals that were completely race/gender neutral and another 47 entities (23\%) had goals that were predominantly race/gender neutral. This phenomenon was even more pronounced for FY2003. In and of itself, the increasing use of race/gender neutral goals in the FTA's implementation of the DBE program is not a cause for concern. Indeed, few if any would argue that race/gender conscious goals should be used instead of race/gender neutral ones if they are equally effective at remediating discriminatory problems.

To test this, we obtained information from the FHWA containing the affirmative action goals established by state departments of transportation for the years 1998-2004 as well as the amount of disadvantaged business participation achieved in each year. Between 2000 and 2002 approximately $21 \%$ of state DOTs adopted DBE goals that were predominantly race/gender neutral. Another 14\% adopted goals that were entirely race/gender neutral. Although Federal highway construction aid dollars increased from \$14.7 billion in 1998 to \$24.3 billion in 2002, and although overall disadvantaged business goals remained virtually constant during this time, the proportion of federal aid dollars actually awarded to such businesses declined almost 30\% between 1998 and 2002. The vastly increased use of race/gender neutral goals in the implementation of the USDOT DBE program appears to have been accompanied by greatly reduced participation by minority and women firms.

Since 1998 the FAA has not been reaching the goals it set for itself for minority-owned businesses but it has done so for women-owned. Indeed, there is some evidence that the gap between the goal and achievement has widened over time for minority businesses. For example, in 2004 the FAA had a goal of 10\% for minority-owned businesses but achieved only 7\% whereas it had a goal of 5\% for women-owned businesses and accomplished 6\%.In 2005 the minority goal was cut to $5 \%$. We were unable to obtain information on the relative importance of race conscious versus race neutral goals in the FAA program. ${ }^{7}$

In the next section we examine the history of affirmative action programs in construction. In section three we document what happens when race and gender conscious programs are halted. In section four we perform an econometric analysis of self-employment to determine how effective the various affirmative action programs have been. Our main findings are that the programs have not helped minorities to become self-employed or to raise their earnings but have

\footnotetext{
${ }^{7}$ See www.sbo.faa.gov/sbo/goalsprevious.asp.
} 
improved the position of white females. We find that there has been a growth in incorporated self-employment rates of white women in construction such that currently they are significantly higher than those for white men. The data are suggestive of the possibility that some of these companies are 'fronts' which are actually run by their white male spouses to take advantage of the affirmative action programs.

\section{A History of Affirmative Action Programs in Public Construction.}

Congressional efforts to promote minority-owned business enterprises have their origins in Section 8(a) of the Small Business Act of 1958, which originally empowered the Small Business Administration (SBA) to "set-aside" certain federal contracts for performance by "small business concerns or others."8 The SBA initially used its powers under Section 8(a) to hire businesses agreeing to locate in or near certain low-income areas and provide training and jobs to the unemployed or underemployed residents of those areas. ${ }^{9}$

Between 1969 and 1971 the Executive branch encouraged the focus of the 8(a) program to shift from creation of jobs in low income areas to creation of demand for minority-owned business enterprises (MBEs). Executive Order 11458 (1969) established the Office of Minority Business Enterprise (OMBE) within the Department of Commerce and directed the Secretary of Commerce to develop programs and coordinate interagency activities to promote the growth of minority business. Executive Order 11625 (1971) further extended the mission of OMBE, including supply-side measures such as subsidizing the provision of technical and managerial assistance to MBEs by various public and private organizations and additional demand-side measures requiring "best efforts" by prime contractors to utilize minority businesses as subcontractors on large federal contracts. ${ }^{10}$ In 1973 the Justice Department also promulgated regulations pursuant to Title VI of the Civil Rights Act of 1964 prohibiting state and local governments from discriminating against minority contractors in federally-funded programs. ${ }^{11}$ In 1978 Congress provided a statutory basis for promoting minority business development through the SBA 8(a) program with the passage of Public Law 95-507. The first specific numerical goals for minority participation in federal contracts appeared as part of the Public Works Employment Act of 1977 which directed that 10 percent of the funds provided by the act be expended with MBEs. ${ }^{12}$

In 1982, through the U.S. Department of Transportation (USDOT), Congress established the Disadvantaged Business Enterprise (DBE) program, designed to increase the participation of MBEs and other socially and economically disadvantaged businesses in federally-assisted highway, transit, and airport contracts. The Surface Transportation Assistance Act of 1982 and

\footnotetext{
${ }^{8} 15$ USCS § 637(a). Service, Library of Congress, 2004.

${ }^{10} 48$ CFR 19.201, 19.702 (superceding 41 CFR 1-1.1302, 1310-2).

1128 CFR 42.104(b)(vi).

${ }^{12} 42$ U.S.C.A.§ 6705(f)(2).
}

9 Dale, Charles V. “Affirmative Action Revisited: A Legal History and a Prospectus,” Congressional Research 
the Airport and Airway Improvement Act of 1982 contained the first statutory provisions for DBEs, requiring that a minimum of 10 percent of the funds provided by the acts be expended with small businesses owned and controlled by socially and economically disadvantaged individuals. Non-minority women-owned businesses (WBEs) were not included initially as socially and economically disadvantaged individuals. The Surface Transportation and Uniform Relocation Assistance Act of 1987 continued the DBE program and included non-minority women in the statutory definition of socially and economically disadvantaged individuals, thereby allowing states to use contracts with both minority- and women-owned businesses (MWBEs) to meet their DBE goals. The Intermodal Surface Transportation Efficiency Act of 1991 (ISTEA), the Transportation Equity Act for the $21^{\text {st }}$ Century of 1998 (TEA-21), and the Safe, Accountable, Flexible, Efficient Transportation Equity Act: a Legacy for Users (SAFETEA-LU) of 2005 reauthorized the program, continuing the combined 10 percent provision for participation by minority-owned and non-minority women-owned DBEs. ${ }^{13}$

Following the lead of the federal government, policies to promote the inclusion of MWBEs in government contracting activities spread gradually throughout the 1970s and 1980s to many states and municipalities throughout the U.S. States such as Texas, Illinois, and Maryland and cities such as Chicago, Denver, San Francisco, Baltimore, and Atlanta also established their own demand-side goals programs on their construction spending on projects funded by state or local dollars. These programs have taken various forms, employed different approaches to goalsetting, and achieved different results. Some jurisdictions have included supply-side programs as well, for example to assist small firms in their access to capital, obtaining surety bonds, or obtaining technical or managerial assistance. Some of the demand-side programs and most if not all of the supply-side programs are race neutral in nature in that they are designed to help all small firms not just minority-owned or woman-owned firms. By 1989 more than 35 states and almost 200 local governments had passed some sort of affirmative action initiative directed at MWBEs. ${ }^{14}$

There is a presumption underlying all of this legislation that discrimination against minorities and women in business, and especially in the construction industries where much of the legislation has focused, continues to persist. Senator Lautenberg, for example, stated during the course of Senate hearings in relation to TEA-21.

"Jim Crow laws were wiped off the books over 30 years ago. However, their pernicious effects on the construction industry remain. Transportation construction has historically relied on the old boy network which, until the last decade, was almost exclusively a white, old boy network. ... This is an industry that relies heavily on business friendships and relationships established decades, sometimes generations, ago — years before minority-owned firms were even allowed to compete."15

\footnotetext{
${ }^{13}$ See http://osdbuweb,dot.gov/documents/pdf/legislation/SAFETEA-LU.pdf

${ }^{14}$ Wainwright (2000), p. 8.

${ }^{15}$ p. 5101 Federal Register / Vol. 64, No. 21 / Tuesday, February 2, 1999 / Rules and Regulations.
} 
The U.S. Supreme Court's decision in City of Richmond v. J.A. Croson Co., 488 U.S. 469 (1989), established the current constitutional contours of permissible race-based public contracting programs. Reversing long established law, the U.S. Supreme Court for the first time extended the highest level of judicial examination to legislation to benefit rather than injure the historic victims of discrimination. However benign the government's motive, race is now always so suspect a classification that its use must now pass the highest constitutional test of "strict scrutiny.”

In affirming the Court of Appeals' determination that Richmond's plan was unconstitutional, Justice O'Connor's plurality opinion rejects the extreme positions that local governments either have carte blanche to enact race-based legislation, or must prove their own illegal conduct before they can enact race-based legislation.

"[A] state or local subdivision ... has the authority to eradicate the effects of private discrimination within its own legislative jurisdiction. . . . [Richmond] can use its spending powers to remedy private discrimination, if it identifies that discrimination with the particularity required by the Fourteenth Amendment. ... . [I]f the City could show that it had essentially become a 'passive participant' in a system of racial exclusion ... . [it] could take affirmative steps to dismantle such a system." 16

Apparently recognizing that the opinion might be misconstrued to categorically eliminate all race-conscious contracting efforts, Justice O’Connor closes with these admonitions:

"Nothing we say today precludes a state or local entity from taking action to rectify the effects of identified discrimination within its jurisdiction. If the City of Richmond had evidence before it that non-minority contractors were systematically excluding minority businesses from subcontracting opportunities it could take action to end the discriminatory exclusion. Where there is a significant statistical disparity between the number of qualified minority contractors willing and able to perform a particular service and the number of such contractors actually engaged by the locality or the locality's prime contractors, an inference of discriminatory exclusion could arise. . . . Under such circumstances, the City could act to dismantle the closed business system by taking appropriate measures against those who discriminate on the basis of race or other illegitimate criteria. . . In the extreme case, some form of narrowly tailored racial preference might be necessary to break down patterns of deliberate exclusion. . . . Moreover, evidence of a pattern of individual discriminatory acts can, if supported by appropriate statistical proof, lend support to a local government's determination that broader remedial relief is justified." ${ }^{\prime 7}$

Thus,

${ }^{16}$ Id. at $491-492$.

${ }^{17}$ Id. at 509 (citations omitted). 
"[t]he strict scrutiny test involves two questions. The first is whether the interest cited by the government as its reason for injecting the consideration of race into the application of law is sufficiently compelling to overcome the suspicion that racial characteristics ought to be irrelevant as far as treatment by the government is concerned. The second is whether the government has narrowly tailored its use of race, so that race-based classifications are applied only to the extent absolutely required to reach the proffered interest. . . . The strict scrutiny test is thus a recognition that while classifications based on race may be appropriate in certain limited legislative endeavors, such enactments must be carefully justified and meticulously applied so that race is determinative of the outcome in only the very narrow circumstances in which it is relevant." Adarand Constructors, Inc. v. Peña, 965 F.Supp. 1556, 1569 (D. Colo. 1997) (“Adarand IV”).

In addition to the federal government many cities and states had adopted demand-side goals programs and supply-side technical assistance programs. After Croson, however, numerous city, state, and federal programs that had race conscious components were challenged in the courts and, in most cases, ruled unconstitutional. Important cases include: City of Richmond; City of Philadelphia; City of Columbus; Fulton County, Georgia (Atlanta); Dade County, Florida (Miami); King County, Washington (Seattle); Cook County, Illinois (Chicago); Hillsborough County, Florida (Ft. Lauderdale); the District of Columbia; the State of Ohio, the State of Florida, and the Michigan DOT. In some jurisdictions a settlement was reached before the courts ruled and the program was dropped entirely such as in the South Florida Water Management District, the City of Charlotte and the City of Memphis. The State of Texas DOT added white males to its program effectively making the program race-neutral, while the State of Maryland and the City of Jacksonville adopted revised race-conscious programs. In other jurisdictions such as the City of Columbus and the New Jersey DOT race conscious programs were replaced with programs that were entirely race blind. ${ }^{18}$ Other jurisdictions dropped their programs for fear of being sued.

The challenging party has the ultimate burden of production and persuasion that an affirmative action program in public contracting is unconstitutional. While the government has the burden of producing a 'strong basis in evidence' in support of its program, it does not bear the burden to prove it constitutional. When the statistical information is sufficient to support the inference of discrimination, the plaintiff must prove that the statistics are flawed. A plaintiff cannot rest upon general criticisms of studies or other evidence; it must carry the case that the government's proof is inadequate to meet strict scrutiny, rendering the legislation illegal. The determination whether a plaintiff has met this burden is a question of law, subject to de novo review.

Much of the dissension in the case law has revolved around what type of evidence is sufficiently 'strong' to establish the continuing existence and effects of economic discrimination against minorities resulting in diminished opportunities to do business with the government. Discrimination has to be demonstrated through the use of statistics and economic models to

\footnotetext{
${ }^{18}$ Whether affirmative action procurement programs that benefit women are subject to the lesser constitutional standard of 'intermediate scrutiny' has yet to be settled by the Supreme Court.
} 
examine the effects of systems or markets on different groups, as well as by evidence of personal experiences with discriminatory conduct, policies or systems. Specific evidence of discrimination or its absence may be direct or circumstantial, and include economic factors and opportunities in the private sector affecting the success of Minority and Business Owned Enterprises (MWBEs). Anecdotal evidence of experiences with discrimination in contracting opportunities, including testimony from other governments' studies and programs, is relevant since it goes to the question whether observed statistical disparities are due to discrimination and not to some other no-discriminatory cause or causes. Discrimination by prime contractors, unions, bonding companies, suppliers and lenders has also been found relevant to the creation of barriers both to minority subcontractors' business formation and to their success on governmental projects. Race- and gender- neutral approaches have become a necessary component of a defensible MBE program despite the fact that as noted by Ray Marshall, there remains little or no evidence that race blind measures have anything other than minimal impacts.

"Because of the difficulties in applying general antidiscrimination measures to businesses, federal, state and local governments have used their purchasing power as the most effective way to overcome the effects of, and to prevent, discrimination against minority businesses. The federal government adopted this approach after other so-called 'race neutral' approaches had failed to overcome the effects of discrimination in the construction industry". 19

Whether every race-neutral approach must be implemented and then proven to be ineffective before race-conscious remedies may be utilized, remains uncertain.

Recently there have been a number of cases that have reversed the immediate post-Croson trend and found affirmative action programs to be constitutional. ${ }^{20}$ These include Sherbrooke Turf $v$. Minnesota DOT and Gross Seed v. Nebraska DOT that related to the federal DBE program. ${ }^{21}$ Here, the courts ruled that the U.S. Congress had established 'compelling interest' and that the state programs were 'narrowly tailored.' In both these cases the U.S. Department of Justice and the U.S. Department of Transportation acted as intervenors, with the U.S. government defending the programs. $^{22}$ Recently the U.S. District Court in Illinois, in the case of Northern Contracting Inc vs. the State of Illinois Department of Transportation (IDOT), ruled in favor of IDOT, citing the findings in the Sherbrooke Turf case as precedent, finding a compelling need for IDOT's plan which was "narrowly tailored to the goal of remedying the effects of racial and gender

\footnotetext{
${ }^{19}$ Ray Marshall (2000), citing Croson, 488 U.S. 469, 550 (Marshall, J., dissenting), noting that while race neutral measures are "theoretically appealing, [they] have been discredited as ineffectual in eradicating the effects of discrimination" in the construction industry.)

${ }^{20}$ See Holt (2003).

21 Sherbrooke Turf, Inc. v. Minnesota Department of Transportation, et al, No.02-1665 (8 ${ }^{\text {th }}$ Cir. October 6, 2003) (Sherbrooke III), and Gross Seed Company v. Nebraska Department of Roads, et al, No. 02-3016 (8 ${ }^{\text {th }}$ Cir. October 6 , 2003).

22 Appellee briefs filed by the U.S. government in the district court in Western States, and in both the district and the $8^{\text {th }}$ Circuit Court of Appeal in Sherbrooke Turf and Gross Seed, along with the court decisions are available at http://www.usdoj.gov/crt/app/briefs_aa.htm
} 
discrimination within the construction industry."23 In a similar case relating to the federal DBE program of Western States Paving $v$. State of Washington Department of Transportation (WsDOT), the court granted the defendant summary judgment dismissing the case but this was overturned in part on appeal to the $9^{\text {th }}$ Circuit Court of Appeals because WsDOT did not offer any evidence of discrimination in the Washington state construction industry and hence their program was not narrowly tailored. The $9^{\text {th }}$ Circuit did, however, find the DBE Program constitutional on its face.

Two further cases relate to programs established not by the federal government with the approval of Congress but by two cities - Denver and Chicago. In Concrete Works v. the City and County of Denver and in Builders Association of Greater Chicago (BAGC) v. City of Chicago affirmative action programs for MWBEs in construction were challenged as unconstitutional. The defendants did not have the benefit of arguing that Congress had established compelling interest and thus had a higher bar to reach since they had to establish compelling interest themselves within their own jurisdictions. Despite this, after lengthy trials, defendants in both cases successfully argued they had established a compelling interest in having their programs and in the Concrete Works case, after a decision of the $10^{\text {th }}$ Circuit Court of Appeals overturning the lower court's decision, that the program was narrowly tailored. ${ }^{24}$ The U.S. Supreme Court refused to overturn the $8^{\text {th }}$ and $10^{\text {th }}$ Circuit Appeals Court decisions respectively in Concrete Works, Sherbrooke Turf and Gross Seed by refusing to grant writs of certiorari. In the Concrete Works case, however, Justices Scalia and Rehnquist wrote a dissent from denial of certiorari. ${ }^{25}$ In the BAGC case the district court temporarily enjoined the program but permitted the City of Chicago to take steps to narrowly tailor its program, which it did a few months later when it introduced a new program. The authors were defendants' experts in the Concrete Works; Sherbrooke Turf, Gross Seed, BAGC and Northern Contracting cases. ${ }^{26}$

A recent report on affirmative action programs across all federal contracting by the U.S. Commission on Civil Rights (2005) makes interesting reading and shows the diversity of views

${ }^{23}$ Northern Contracting Inc v. the State of Illinois Department of Transportation (N.D., Il.), No. 00C4515 September $8^{\text {th }} 2005$, p. 52.

${ }^{24}$ Initially the trial court in Concrete Works found the program unconstitutional but the district court's decision was overturned by the $10^{\text {th }}$ Circuit Court of Appeals. In both the Gross Seed and Sherbrooke Turf cases the $8^{\text {th }}$ Circuit Court of Appeals, in an opinion where it consolidated the two cases, upheld the lower court's decision that Congress had established compelling interest for the programs and that defendants had established them to be narrowly tailored.

${ }^{25}$ In Concrete Works the U.S. government filed amicus briefs on the side of the City and County of Denver with the $10^{\text {th }}$ Court of Appeals opposing the district court's decision declaring the program unconstitutional. See http://www.usdoj.gov/crt/briefs/concrete.htm. The $10^{\text {th }}$ circuit court of Appeals decision is available at http://www.usdoj.gov/crt/app/briefs_aa.htm. The U.S. Supreme Court dissent by Scalia and Rehnquist in Concrete Works is available at www.supremecourtus.gov/opinions/03pdf/02-1673.pdf.

${ }^{26}$ Both authors contributed to expert reports for defendants in all five of these cases, Blanchflower testified at trial in Concrete Works, Gross Seed and BAGC and Wainwright testified at trial in Northern Contracting. Blanchflower and Wainwright both gave depositions in Sherbrooke Turf but this case did not go to trial but rather was dismissed under summary judgment in favor of defendants. 
on the issue. ${ }^{27}$ The majority report extols the virtues of race neutral contracting but does not present any evidence of discrimination, for example, by race or gender in construction or elsewhere or whether it has improved or worsened over time, or how it varies by sector and/or location. There is merely a presumption in the report that race neutral measures work, unaccompanied by any evidence one way or the other to justify such a conclusion. A considerable part of the report consists of a dissent by Commissioner Michael Yaki who calls the majority report 'fatally flawed" and argues that "there is significant data demonstrating that socially and economically disadvantaged firms continue to lag well behind where they should be in proportion to the country's demographic composition or labor force representation.” (p86). He presents statistical evidence to support his arguments in a "Dissent Appendix."

There is evidence since the 1980s in the United States that race and gender conscious affirmative action programs in construction and elsewhere can have a substantial impact.

Enchautegui et al (1997) found that there are substantial disparities between the share of public contract dollars received by minority-owned firms and the share of all firms that they represent. The difference in these disparities is especially marked between jurisdictions which have affirmative action programs and those that have never had them or removed them. The disparities are much less where affirmative action programs exist.

Chay and Fairlie (1998) examined whether the set-aside programs established in many of the largest U.S. cities during the 1980s had an impact on the self-employment rates of blacks and whites. Their analysis was based on data from the Current Population Survey for 1979-1988. They stopped at 1988 since the 1989 Croson decision led to the dismantling of set-aside programs in many cities. They had some difficulty in ascertaining the exact starting dates of a number of the programs because there were inconsistencies in the data sources used. The paper examined what happened to self-employment rates when programs were introduced. They found that self-employment rates in construction for black men increased from about $12 \%$ before the programs were introduced to about $18 \%$ after. On the other hand, rates for white men were relatively stable before and after the programs were passed. Chay and Fairlie argued that "these figures provide strong evidence that set-aside programs worked".

As previously indicated, a condition of accepting federal funding for highway construction, state departments of transportation need to ensure a proportion of those dollars are awarded to DBEs a large percentage of which are owned by minorities and women. A number of these states do not have a goal program when they spend their own dollars. Utilization of minority- and femaleowned firms in such states is much higher where federal dollars are used than where state dollars are used. Figure 1 provides the details based on data for fiscal year 1996. In all of these ten states, utilization of DBEs was higher on federally funded projects with goals than on state funded contracts without them.

New data have recently become available from the Federal Highways Administration on participation of DBEs on federal DBE programs in seventeen states in 2002 that do not have such a program for spending on highway construction funded by state dollars. Usefully,

${ }^{27}$ www.usccr.gov/pubs/080505_fedprocadarand.pdf 
information is available in these states on firm's DBE status under the auspices of the federal program. As is apparent from Table 1, of the seventeen states only three - Florida, Mississippi and Wyoming have higher utilization of DBEs on state projects without goals than is found when federal money is spent with attached goals. Overall, utilization of DBEs is $10 \%$ when goals are in place and $5.7 \%$ when they are not. We now turn to examine what happens when such goals programs are removed or replaced with race-neutral efforts in response to litigation or the threat thereof.

\section{What happens when race conscious affirmative action programs are halted?}

Over the last few years the courts have either permanently or temporarily halted programs that benefited MWBEs in many jurisdictions across the United States. In some cases the programs have started up again when the injunctions were lifted or a new program instituted. This provides an opportunity to examine what happened to utilization of such firms when the program is removed. This is a good way to get at the scale of the impact of the programs. As can be seen below the impact was devastating - utilization dropped to zero in at least one case. Examples include the following.

- After the Supreme Court invalidated Richmond's minority business set-aside program, minority participation fell from 30 percent to 4 percent, representing a drop of more than 87 percent.

- In Atlanta, minority participation in City contracts declined from about 35 percent in 1988 to 14 percent in 1989 after the Georgia Supreme Court invalidated the city's program.

- In Fulton County, minorities increased their participation in county procurement business from .004 percent in 1977-79 before the county's program was adopted, but declined from 17 percent to 1.7 percent after that program was temporarily enjoined in 1986.

- In Philadelphia, public works subcontracts awarded to minority-owned firms fell by 97 percent during the first month after the city's program was enjoined in 1990.

- In Hillsborough County, Florida, minority contractor participation fell by 99 percent after their program was struck down.

- In the City of Elyria, Ohio (a suburb of Cleveland), minority participation in public works contracting virtually disappeared after their program was permanently enjoined by the court in 1991. Participation fell from approximately \$1 million dollars (25 percent) in 1991 to $\$ 26,000$ (0.6 percent) in 1992. In 1993, participation fell further to a mere $\$ 19,000$ (less than one-half of one percent of the total).

- In the City of Tampa, black participation in city contracting fell by 99 percent and Hispanic participation fell by 50 percent.

- In San Jose, California, minority participation in the city's prime contracts fell by more than 80 percent in 1989 when their program was originally suspended.

- In the wake of Proposition 209, the State of California Department of Transportation halved 
its state-funds for Minority and Women-Owned Business Enterprise (MWBE) goal from 20 percent to 10 percent. Subsequently, MWBE participation fell from 25.8 percent in 1995 to 14.7 percent in 1996 to 12.2 percent in 1997.

In a study of disadvantaged business enterprises the General Accounting Office (2001) reported that MWBE participation in transport contracting declined after Louisiana's nonfederal program was discontinued. As shown in Figure 2, taken from the GAO report, MWBE participation in state transportation contracting increased from 1992 to 1995. In 1996, the year the nonfederal program was discontinued, the participation rate of MWBEs in state transportation contracting dropped and continued to decline over the next 4 years (Page 40). The GAO reported that an official from Louisiana attributed the decline in MWBEs' participation in state transportation contracting to the removal of affirmative action requirements on state funded projects and the realization by contractors that efforts to include MWBEs were no longer necessary.

The GAO also obtained data on DBE participation in Louisiana's federal DBE program from 1995 to 2000. In their review of the data on DBE and MWBE participation in federally assisted and state contracting, they did not observe a shift of MWBEs to federally assisted contracts after the Louisiana's MWBE program was discontinued. This evidence is entirely consistent with the evidence presented above that the goals programs work: removing them impacts negatively the usage of minority and women-owned firms. ${ }^{28}$

On September $2^{\text {nd }}, 1998$, in the case of Sherbrooke Turf v. the Minnesota Department of Transportation and Judge Rosenbaum enjoined Minnesota Department of Transportation's (MnDOT) MWBE Program. In August 1999, Judge Rosenbaum ruled that the injunction only applied to ISTEA and not to TEA-21. On April 28, 2000, MnDOT let its first contracts using goals under the TEA-21 MWBE Program. MnDOT did not operate any sort of MWBE program during the time the program was enjoined. MnDOT also did not certify any new MWBEs during that time. MnDOT did not monitor the certification status of MWBEs certified prior to the injunction. Strictly speaking, there were no certified MWBEs during the 1999 construction season because there was no program under which minority and female owned firms could be certified. During the period of enjoinment, MnDOT continued to monitor the participation in federal aid projects by the MWBEs certified under the enjoined program. This monitoring spanned the 1999 construction season, which is based on the federal fiscal year ("FFY"), October $1^{\text {st }}, 1998$ through September $30^{\text {th }}, 1999$.

When monitoring MWBE participation during the period of enjoinment, MnDOT relied upon prime contractors voluntarily submitting information to MnDOT. MnDOT did not receive a 100

\footnotetext{
${ }^{28}$ During the Senate hearings on TEA-21 Senator Baucus cited the experience of Michigan where participation in the state-funded portion of the highway program fell to zero in a nine month period after the state terminated its MBE/WBE program while the federal program was able to maintain $12.7 \%$ participation. Senator Kerry also cited similar decreases in MBE/WBE participation in Louisiana, Hillsborough County, Florida, and San Jose, California. Senator Moseley-Braun added the examples of Arizona, Arkansas, Rhode Island and Delaware where state-funded projects without a MBE/WBE program have significantly less MBE/WBE participation than federally funded projects subject to the highway program. Senator Kennedy added Nebraska, Missouri, Tampa, and Philadelphia to the list of jurisdictions that experienced precipitous drops in MBE/WBE participation after goals programs ended. See p 5101 Federal Register / Vol. 64, No. 21 / Tuesday, February 2, 1999 / Rules and Regulations.
} 
percent return rate from the contractors. During the 1999 construction season, MWBEs certified under the enjoined MWBE Program received approximately 2.6 percent of the contract dollars. That number was subsequently used by MnDOT to reflect the amount it believed it could achieve through race and gender neutral means. When MnDOT began implementing its TEA-21 MWBE Program, it required all firms seeking MWBE certification under the TEA-21 MWBE Program to submit an application. Firms certified under the enjoined MWBE Program were required to submit a new application.

MnDOT examined their construction expenditure data for the calendar year 1996-1999 and produced the results reported in Table 3a. The total amount of contract dollars grew from \$210 million in FFY96 to \$296 million in FFY 1999. In the years 1996-1998 when the program was in existence the proportion of contract dollars given to MWBEs averaged 10.8 percent, split up as 2.2 percent for minority men; 0.1 percent for minority women and 8.5 percent for Caucasian women. For the year 1999 when the program was enjoined, the proportion of contract dollars paid to MWBEs fell to 2.25 percent. The amount paid to women fell to 1.95 percent but the most precipitous decline was for minority men who in 1999 received only 0.28 percent of contract dollars. In 1999 the amount of dollars received by minority males fell from just over $\$ 6.5$ million to $\$ 841,000$. The amount of contract dollars received in 1999 by minority men was only 12.7 percent of the amount they received when the program was in existence. Michigan and Minnesota appear to be similar - remove the goals and the participation of MWBEs falls precipitously. The evidence on the decline in DBE participation when the program was enjoined was used by MnDOT to determine the proportion of their goals that could be obtained by race neutral means.

Once Judge Rosenbaum lifted the injunction on the program, utilization rose again rapidly to levels comparable to those pertaining prior to the temporary restraining order. Table 3b provides further supporting evidence: it provides quarterly information for the five quarters for which data are available since the program restarted and MWBEs once again were re-certified. It shows dramatic increases in the use of MWBEs once the program was reintroduced. MWBEs gained no contracts at all in Q1- FFY 2000. By the $1^{\text {st }}$ quarter of 2001 participation of MWBEs had risen to 8.7 percent. Most notable was the increase in the participation of minority men.

The GAO report also examined the evidence for Minnesota and confirmed the findings that after the discontinuance of Minnesota's federal DBE program in 1998, Disadvantaged Business Enterprises (DBEs) participation in federal transportation contracting dramatically declined. This evidence is confirmed in Figure 3 taken from their report, which confirms dramatic declines post 1998 both in the number of construction contracts and dollars awarded to DBEs.

There is also evidence on the impact of the removal of set-aside programs in the City of Chicago. First the Chicago Metropolitan Water District had a very low utilization of firms owned by women or minorities during the 1970s. From 1972-1974 Minority Business Enterprises (MBEs) utilization in dollars spent was only 0.46 percent. From July 1977- May 1979 it was 2 percent. Effective from May 1979 a goals program was implemented with goals of 10-15 percent on EPA funded contracts. From this point utilization jumped rapidly and remained high during the years the program was in effect, as can be seen below 


\begin{tabular}{|l|l|l|}
\hline May 1979-January 1982 & $12.7 \% \mathrm{MBE}$ & \\
\hline 1982 & $12.3 \% \mathrm{MBE}$ & \\
\hline 1983 & $12.8 \% \mathrm{MBE}$ & \\
\hline 1984 & $12.5 \% \mathrm{MBE}$ & \\
\hline 1985 & $10.6 \% \mathrm{MBE}$ & $2.2 \% \mathrm{WBE}$ \\
\hline 1986 & $12.3 \% \mathrm{MBE}$ & $6.5 \% \mathrm{WBE}$ \\
\hline 1987 & $17.7 \% \mathrm{MBE}$ & $7.7 \% \mathrm{WBE}$ \\
\hline 1988 & $16.8 \% \mathrm{MBE}$ & $7.7 \% \mathrm{WBE}$ \\
\hline 1989 & $13.9 \% \mathrm{MBE}$ & $9.6 \% \mathrm{WBE}$ \\
\hline
\end{tabular}

When the goals program was suspended in 1989, the utilization of MBEs and Women-Owned Business Enterprises (WBEs) dropped dramatically. During the first half of 1989 \$19.6 million of contracts were awarded with the goals still in place. Utilization of MBEs was 23.6 percent with a further to 16.3 percent going to WBEs., half 1989 contracts without goals. During the second half of 1989 when the goals program had gone and contractors were free to determine their own usage of MWBEs of the \$63.6 million awarded only 10.8 percent went to MBEs and a further 7.4 percent went to WBEs. ${ }^{29}$

In 2002 the County of Cook's sub-contractor goals program in construction was struck down. ${ }^{30}$ Prior to the entry of the injunction the Cook County ordinance set - and apparently met - subcontractor goals for MBEs of 30 percent and for WBEs of an additional 10 percent making 40 percent in all. In a subsequent case involving the same plaintiff, evidence was presented at trial from Cook County on the utilization of minority and women-owned firms. ${ }^{31}$ When contracts relating to medical equipment and supplies were omitted and restricting the analysis to contracts involving 'dirt' upon examining contracts awarded by Cook County post-litigation in 2001 and thereafter it was found that MBE utilization had fallen dramatically. Out of a total of $\$ 51,045,508.09$ in contract dollars spent, $\$ 19,741,139.25$ was for equipment and was removed from the calculations. This leaves $\$ 31,304,368.83$ of which $\$ 4,016,641.58$ went to MBEs (12.83 percent) and $\$ 1,579,768.97$ went to WBEs (5.05 percent). Overall then $\$ 5,596,410.55$ out of $\$ 31,304,368.83$ went to MWBEs (17.88 percent). This is a dramatic drop from the preinjunction levels at a time when these contractors were likely aware that they were under scrutiny and likely to be on their best behavior as they were plaintiffs in ongoing litigation on the same issue with an overlapping jurisdiction.

A race and gender conscious MWBE program appears to be needed not just to overcome the effects of past discrimination, but to prevent future discrimination as well. Several state Departments of Transportation such as Arizona, Arkansas and Connecticut have quite high utilization of MWBEs when they spend federal dollars that require their use, but the same

\footnotetext{
${ }^{29}$ These numbers are taken from the Chicago Metropolitan Water District Study, 1990

${ }^{30}$ Builders Association of Greater Chicago vs. County of Cook, in the U.S. District Court for the Northern District of Illinois Eastern Division, Case \# 96 c 1121, November 2, 2000, Decided

${ }^{31}$ Builders Association of Greater Chicago vs. City of Chicago in the U.S. District Court for the Northern District of Illinois Eastern Division, Case No. 96 C, 1122, December $29^{\text {th }}$ 2003, Decided.
} 
organizations make use of hardly any of these firms when they spend their state monies, which do not have goals programs. The gaps are not small - in Rhode Island for example they were 12.5 percent and zero respectively. Evidence from many state and municipal jurisdictions suggests that once these programs are removed the utilization of MWBEs drops precipitously. Analogously, when they are put in place, utilization of minority and women-owned firms increases. There is no evidence that we are aware of that suggests that when programs are removed utilization of minorities and women goes up or remains constant. The evidence is universally that utilization drops when these programs are enjoined or dropped. Goals programs are effective in promoting the utilization of MWBEs in construction. We are aware of no evidence that suggests that race neutral programs improve the relative position of minorities. The big question is how effective have these programs been in improving the position of minorities and women in the construction labor market? Race conscious affirmative action programs appear to work when they are in place but legal action has removed and/or severely restricted their presence. To what extent has this impacted the position of minorities and women in construction? This is what we now examine.

\section{Analysis of the Impact of Affirmative Action Programs in Construction.}

We now turn to examine the construction labor market and see what has happened to the selfemployment rate of women and minorities over time. Given the existence of Prevailing Wage Laws $^{32}$ and widespread affirmative action programs it is of interest to determine whether the position of women and minorities in the construction sector has improved or worsened over time. In particular it is of interest to examine the changes post-Croson, so we compare selfemployment rates pre-1991 to the post-1991 rates. We show that the position of white females appears to have improved but there is little or no evidence to support that conclusion in the case of African Americans or Hispanics. The evidence is more mixed for other racial groups such as Asians and Native Americans.

Here we concentrate on publicly available nationally representative data on individuals. We look here at both the owners of firms as well as their employees. At the level of the individual, of course, we have very good data on the individual's education, race and gender. It is not unreasonable to look at the self-employed given our finding above from the 2002 Economic Census Survey of Minority-owned Business Enterprises that approximately 74\% of construction firms have no employees. We have data both on the unincorporated self-employed as well as the incorporated self-employed who receive wages and salaries but are not counted as part of the official self-employment rate in the U.S. government counts.

A continuing puzzle in the literature in the U.S. has been why the self-employment rate of black males is one third of that of white males and has remained roughly constant since 1910. Moreover, minorities start businesses at much lower rates than non-Hispanic whites. Using the Public Use Microdata Samples (PUMS) data from the 1990 Census, Wainwright (2000) demonstrated that these disparities persist even when factors such as geography, industry, occupation, age, education and assets are held constant.

\footnotetext{
${ }^{32}$ Prevailing Wage Laws (PWLS) exist at the federal and in addition the majority of states have their own PWLs. The intent of such legislation is primarily to protect the local wage rates in construction. These laws appear to have only small impacts on construction labor markets (Kessler and Katz, 2001).
} 
Fairlie and Meyer (2000), rule out a number of explanations for the difference in the selfemployment rates of white and black males. They found that trends in demographic factors, including the Great Migration and the racial convergence in education levels "did not have large effects on the trend in the racial gap in self-employment" (p. 662). They also found that an initial lack of business experience "cannot explain the current low levels of black self-employment." Further they found that "the lack of traditions in business enterprise among blacks that resulted from slavery cannot explain a substantial part of the current racial gap in self-employment” (p. 664 Fairlie (1999) and Wainwright (2000) have shown that a considerable part of the explanation of the differences between the African American and white self-employment rate can be attributed to discrimination. Bates (1989) finds strong supporting evidence that racial differences in levels of financial capital have significant effects upon racial patterns in business failure rates. Fairlie (1999) also found that the black exit rate from self-employment is twice as high as that of whites.

The gap between the black and white male self-employment rates has persisted for the best part of a century. The white male self-employment rate decreased from its highest point in 1910 (16.0 percent) to its lowest point in 1970 (10.0 percent). In 1970 the downward trend in the selfemployment rate ended and began a climb to 11.4 percent in 1990 . Since that time the rate has declined. The similar trends in the white and black rates resulted in a roughly constant black/white ratio during the past 80 years. As Fairlie and Meyer (2000) note:

"The constancy of the black/white ratio is surprising in light of the substantial gains blacks have made in education, earnings and civil rights during the twentieth century... and the numerous government programs created to promote minority business ownership” (p. 656)

In contrast, there has been a striking growth over time in the self-employment rate of females. Devine (1994) showed, using the March Current Population Survey data that the number of selfemployed females aged 18-64 in the non-agricultural sector increased by 2.2 million or 145 percent between 1975 and 1990. This represented an increase in the self-employment rate from 4 percent to 6.6 percent.

If the various affirmative action programs had been successful we might expect to see a growth in the number of firms owned by women and minorities, an increase in the self-employment rate, an increase in the earnings of women and minority business owners. We do not; discrimination against minorities in general, and African-Americans and Hispanics in particular, continues to persist despite efforts on the part of state, federal and local governments to speed its demise. ${ }^{33}$

\footnotetext{
33 One thing that makes construction an attractive sector for affirmative action is the relatively large importance of the government in that sector - hence more leverage. Total spending on construction in 2004 was \$1,027,736 million. Of this $77.7 \%$ was private, made up of $54.8 \%$ private residential and $22.9 \%$ private non-residential; of the remainder 20.6\% state and local and 1.7\% federal (Source: Statistical Abstract of the United States, 2004-5, Table 642). Even in construction though, the private sector is far larger than the public sector. So even with affirmative action in place the public sector is still only a relatively small slice of the overall economy.
} 
Table 3 presents new evidence on self-employment rates by race and gender for the period 19792004 using data from the Merged Outgoing Rotation Group (MORG) files of the Current Population Survey (CPS). Weighted estimates were obtained for each year and then averaged over groupings of years for all industries as well as for construction for white males, white females, African-Americans and Hispanics. Additional data are available for Asians/Pacific Islanders and Native Americans since 1992 but they are excluded from this table as there is no long run consistent time series. We examine them in detail below. Data are presented for total self-employment which is the sum of incorporated and unincorporated as well as separately. The figures in the table are percentages so 3.6 in the top left of the table should be interpreted as $3.6 \%$ of employed white males on average from 1979-1983 were classified as incorporated selfemployed, compared with $11.5 \%$ who were unincorporated in part B of the Table and hence $15.1 \%$ overall in part $\mathrm{C}$ and so on. The main findings from the table are as follows.

1) There has been a growth in the proportion of workers who are classified as incorporated selfemployed that the Census Bureau counts as wage and salary workers.

2) The self-employment rate of white males, whether incorporated or unincorporated, is markedly higher than is the case of any other group.

3) There has been a decline in the unincorporated and the overall self-employment rate of white males but increases for the other groups.

4) Construction self-employment rates, incorporated and unincorporated, have declined for white males but increased for white females, blacks and Hispanics.

5) Incorporated self-employment rates for white women in construction are now higher than they are for white males.

6) The differential between the overall self-employment rates of white males and white females in construction has narrowed dramatically over time. The narrowing is much more apparent than is found for 'all Industries'.

7) The differential between the overall self-employment rates in construction of white males and blacks has narrowed but less than it has for white women.

8) The differential between the overall self-employment rates in construction of white males and Hispanics has widened over time.

We now move on to examine in more detail the disparity in business formation/self-employment rates between racial and ethnic minorities and non-minorities. ${ }^{34}$ We examine the private sector in general as well as construction in particular. Blanchflower $(2000,2004)$ provides summaries of the literature, and compares the determinants of self-employment in the U.S. with that in other OECD countries. Probit regression is used to examine the relationship between whether a person is self-employed (yes or no) and a set of socioeconomic characteristics of that person. The data used first are from the MORG files of the CPS. Data are available in a comparable form from

\footnotetext{
${ }^{34}$ We use the phrases "business formation rates" and "self-employment rates" interchangeably in this chapter.
} 
1979 and the most recent comparable data are from 2004. Results are also presented using data from the 2000 Census. The sample used in these regressions includes men and women who were working at the time they were interviewed either as self-employed (dependent variable $=1$ ) or as a private sector employee (dependent variable=0). Controls for age, location, industry, and education are included along with indicators for race and gender. Coefficients represent percentage point differences between a minority group and comparable whites-comparable in age, location, industry, and education. The dependent variable is set to zero if the individual is a private sector employee and 1 if self-employed, either incorporated or unincorporated. These equations are estimating the probability of being self-employed, holding constant the named characteristics.

In 2002 the industry classification system changed from the Standard Industrial Classification (SIC) to using the 1997 North American Industry Classification System (NAICS). While many of the individual SIC industries correspond directly to industries as defined under NAICS, most of the higher level groupings do not. Particular care has to be taken in comparing data for retail trade, wholesale trade and manufacturing which are sector titles used in both the SIC and NAICS but cover somewhat different groups of industries. In the case of construction some changes affecting it are within construction itself but in the NAICS it now includes industries that were previously classified in other sectors. For this reason we only make use of data for 2003 and 2004 in columns 5-7 which are for construction because of the difficulty in obtaining consistent industry codes for the All Industries grouping over these years.

Columns 1, 3 and 4 of Table 4 are for the pre-Croson period 1979-1991 and columns 2 and 5-7 for the subsequent post-Croson period 1992-2002. Columns 1 and 2 are for all industries while columns 3-7 are restricted to the construction industry. Different education controls are used in the two periods because that is what is available in our data. Columns 4 and 7 are for construction where the dependent variable is set to one if the respondent was incorporated selfemployed, zero otherwise. Column 6 is also for construction where the dependent variable is set to one if the respondent was unincorporated self-employed, zero otherwise.

The main findings from Table 4 are as follows:

1) Holding constant an array of worker and workplace characteristics, white males have highly statistically significantly higher self-employment rates than do any other groups. This is evident in the U.S. as a whole, as well as in Construction.

2) Blacks and Hispanics have especially low self-employment rates in construction.

3) Disparities by race and gender are considerably higher in construction than overall.

4) The magnitude of the difference in self-employment rates between white females and white males has declined over time. Post-Croson the position of white females has improved relative to that of white males. This is true for the private sector as a whole but especially so in construction.

5) The magnitude of the difference in self-employment rates between both blacks and Hispanics 
and white males has narrowed post-Croson overall but remained roughly constant in construction.

6) White females in construction have a significantly higher incorporated self-employment rate than is found for white males in both periods, but the gap has increased post-Croson.

7) Asians/Pacific Islanders and American Indians have significantly lower self-employment rates than white males or white females in construction, driven by their much lower incorporated rates.

Table 5 provides supporting evidence for the findings for construction when a much larger sample from the 2000 census is used. Once again we estimate probit equations which model the probability that an individual is self-employed, holding constant characteristics. We include the same set of controls as used in Table 4 using the MORG data. We exclude any case where one or more of the variables we use have data that are imputed. ${ }^{35}$ Column 1 is for total selfemployment, column 2 for the unincorporated and column 3 for the incorporated. Overall there are significant differences between white males and all race and gender groups overall and for the unincorporated. In column 3 there is a positive and significant coefficient on white females confirming the results in column of Table 4 using the MORG data. The coefficient on the Asian/Pacific Islander variable is insignificant in column 3 and smaller than for other groups in column 1.

The question then is why has there been an increase in incorporated self-employment among white females in construction and not in other sectors. One possibility is that this has arisen to take advantage of the various affirmative action programs that exist in construction and what we are observing is that firms owned by white males are bringing their spouses into the business to take advantage of the programs. Who are these women? In the 2000 Census there are 3,950 white female incorporated business owners whose status was not imputed. Of these $86 \%$ were married compared with $63 \%$ of all white female workers in the construction sector and $68 \%$ of white female unincorporated self-employed in the sector. In terms of family types $71 \%$ of the white female incorporated self-employed were a married couple where both the husband and wife were in the labor force compared with $51 \%$ for all white females in construction and $48 \%$ of the unincorporated self-employed white females.

We examined the occupational mix of both the incorporated and unincorporated self-employed in construction once again using data from the 2000 Census. We omitted any case where the class of worker was imputed. White females who are incorporated self-employed are more likely to be in bookkeeping and accounting and especially likely to be secretaries or administrative assistants. 43\% of white females who were incorporated self-employed were bookkeepers, secretaries or administrative assistants compared with $0.2 \%$ of white men and $23 \%$ of minority women. There is much less difference in the occupation distribution for the unincorporated self-employed between white women and minority women than is the case for the incorporated self-employed. It is likely that what is going on here is that some white females are fronting firms that are actually being run by their white male spouses. They are doing so to

\footnotetext{
${ }^{35}$ For a discussion of the problems of using imputed data in the MORG files of the CPS see Blanchflower and Bryson (2003, 2004 and Hirsch and Schumacher (2002).
} 
take advantage of the benefits of the affirmative action programs. A number of prosecutions around the country have occurred because contracts were fraudulently obtained by companies that were 'fronted' by women and minorities but who were not true owners of the firm and played no active part in its operations. ${ }^{36}$

We now move on to examine whether self-employed minority and white female entrepreneurs receive lower earnings from the businesses they start than white males with similar characteristics receive from their businesses. The ORG files do not contain data on the earnings of the self-employed. Annual earnings, whether from wage or self-employment, are available from the March CPS, also known as the Annual Demographic File. This file also contains the basic monthly demographic and labor force data. In the March CPS, data on employment, earnings, and income refer to the preceding year, although demographic data refer to the time of the survey. Sample sizes are much lower than previously with around 194,000 observations per annum. Information on self-employed earnings is available for approximately 6,000 cases per annum. We supplement this information for construction with data on annual earnings in the year preceding interview (1999) from the 2000 Census.

Table 6 reports estimates of the log of annual self-employment earnings differentials between white females and minority groups and comparable white males. Columns 1 and 2 are for all industries for the periods 1978-1990 and 1991-2001 respectively. Columns 3 and 4 are for construction over the same periods while column 5 is for construction in 1999.

White females, blacks and other minority groups have significantly lower self-employment earnings than white males with similar personal characteristics. This is true in the private sector as a whole and in construction using both the March CPS files and the Census. Interestingly, controlling for occupation in the final column reduces in absolute size the coefficient on the white female dummy - in part their lower earnings are due to their occupations. This is not the case for the other minority groups whose negative differentials are essentially unchanged in columns 5 and 6 . Their lower earnings are not because of their occupations.

One important impediment to minority entrepreneurship is lack of capital. As noted by Nobel Laureate Kenneth Arrow.

"Racial discrimination pervades every aspect of a society in which it is found. It is found above all in attitudes of both races, but also in social relations, in intermarriage, in residential location, and frequently in legal barriers. It is also found in levels of economic accomplishment; that is income, wages, prices paid, and credit extended" (1998, p.91 italics added)

Blanchflower, Levine and Zimmerman (2003) examined the availability of credit to minority and female-owned small businesses using data from the 1993 and 1998 National Surveys of Small

\footnotetext{
${ }^{36}$ For example, James Duff was fined more than \$22 million and sentenced to nearly 10 years in prison in May 2005 after he pleaded guilty to falsely portraying Windy City Maintenance as woman-controlled and Remedial Environmental Manpower as minority-controlled and for defrauding the City of Chicago by taking \$120 million in city contracts reserved for minority- and women-owned companies. Other associates were also fined and received jail time. See the Chicago Sun-Times, May 19 ${ }^{\text {th }}, 2005$ and May 21 $1^{\text {st }}, 2005$ and Chicago Tribune, October $21^{\text {st }}, 2005$.
} 
Business Finances conducted by the Reserve Board of Governors. They demonstrated that loan denial probabilities for African-American owned firms are approximately double those for comparable white-owned firms. Even when African-Americans were able to obtain loans they have to pay higher interest rates. Comparable but smaller effects are found for Hispanics. These differences were not explained by differences in creditworthiness or other observables. Such differences disappeared when the use of credit cards was examined, where the banks were unaware of the race of the applicant. The authors found that firms owned by minorities are discriminated against in the credit market. Similar results were found by Cavalluzzo, Cavalluzzo and Wolken (2002).

Table 7 replicates the finding from Table 3 of Blanchflower, Levine and Zimmerman (2003) using data from both the 1993 and 1998 surveys to estimate a series of equations estimating the probability of a loan application being denied. Variables are included to control for region, industry, type of organization and creditworthiness. It is clear from Table 3 of Blanchflower et al. (2003) paper that adding further controls for characteristics of the loan, other firm characteristics has little substantive impact on the results so for ease of exposition we use this limited set of controls here. In both 1993 and 1998 firms owned by blacks have dramatically higher probabilities of having their loans denied, holding constant their characteristics. Firms owned by Asians/Pacific Islanders also have higher denial rates although the size of the impact, although large, is smaller than for black-owned firms. There is evidence of a large positive effect n 1998 for Hispanics but not in 1993. We find no evidence of any impact for white women. In columns 2 and 4 we include a series of interaction terms between the race and gender variables and a construction dummy to test if the results are different in the Construction industry. They are not: all of the interaction terms are insignificant. Construction firms owned by minorities are discriminated against in the credit market.

In the two surveys of small business finances used above, business owners were asked variously about the main problems that they faced. In the 1993 survey owners were asked about a variety of problems that they had experienced during the preceding 12 months. They were also asked to report the most important issues facing the firm over the following 12 months. In the 1998 survey respondents were asked to report the "single most important problem facing your business today". Credit availability turned out to be the most important problem in all three cases for firms owned by African-Americans and to a lesser extent Hispanics. The problem appeared to be even more serious in construction than elsewhere.

\section{a) Problems firms experienced during preceding 12 months - credit market conditions. (\% reporting serious problem)}

\begin{tabular}{lccc}
\hline & All & Black & Hispanic \\
\hline All industries & 14 & 31 & 23 \\
Construction & 14 & 34 & 23
\end{tabular}

Source: Authors' calculations from 1993 NSSBF 


\section{b) Percentage of firms reporting most important issues affecting them over the next 12 months - credit availability}

\begin{tabular}{lccc}
\hline & All & Black & Hispanic \\
\hline All industries & 6 & 21 & 5 \\
Construction & 7 & 26 & 3
\end{tabular}

Source: Authors' calculations from 1993 NSSBF.

c) What is the single most important problem facing your business today? \% reporting "financing and interest rates"

\begin{tabular}{lccc}
\hline & All & Black & Hispanic \\
\hline All industries & 7 & 18 & 10 \\
Construction & 10 & 36 & 11
\end{tabular}

Source: Authors' calculations from 1998 NSSBF.

In the 1992 Characteristics of Business Owners Survey conducted by the Bureau of the Census firms were asked to report the impact of various kinds of costs upon their profitability (Table 1, p.21). Black and Hispanic-owned firms reported stronger negative impacts of credit market conditions and a lack of financial capital; there are no strong race or gender effects for the various other reasons given. The survey also reported on reasons why a discontinued business was unsuccessful. Black-owned and to a lesser degree Hispanic-owned firms were much more likely to report that the reason was due to lack of access to business or personal loans or credit than was true for other races. ${ }^{37}$

A recent study published by the U.S. Chamber of Commerce (2005) confirms the findings in Blanchflower, Levine and Zimmerman (2003). The survey was conducted in March and April 2005 and detailed the financing problems experienced by small business owners, $95 \%$ of whom had less than 100 employees: 1080 business owners were interviewed and reported that minority businesses rely heavily on credit cards to fund their businesses, often do not apply for credit, even though they need it, for fear of being denied and were especially likely to need working capital. In particular they report that availability of credit is their top problem, exactly as reported by Blanchflower, Levine and Zimmerman. The biggest difference in responses between minorities and Caucasian men and women was availability of credit: 19\% of Caucasian males report credit as their top problem compared with $54 \%$ for minority males - a 35 percentage point difference. There was a 15 percentage point difference for women. In no other category is there more than a 10 percentage point difference for men or women.

\footnotetext{
${ }^{37}$ When asked if lack of financial capital was a serious problem affecting business profitability $29 \%$ of firms owned by white males in the CBO survey answered in the affirmative compared with $46 \%$ owned by blacks and $38 \%$ by Hispanics. For firms that were discontinued $7 \%$ of firms owned by white males reported it was due to lack of access to business capital compared to $16 \%$ for firms owned by blacks and $9 \%$ for Hispanics. A further $3 \%$ of white males said it was due to lack of personal capital compared to a further $8 \%$ for firms owned by blacks and $6 \%$ for Hispanics. See tables 3a and 3b, Blanchflower, Levine and Zimmerman (1998)
} 
Overall, we have shown that there has been no significant change over time in the relative position of African-Americans compared to white males in construction. The probability that they are self-employed is markedly lower than white males and is unchanged over time. Their self-employment earnings remain markedly lower. The probability of being self-employed for Hispanics compared to white males has widened over time although the magnitude of the effects are smaller than for African Americans. The position of white females has improved over time, especially in terms of self-employment probabilities, although it is unclear whether this is simply because firms owned by their white male spouses are transferring ownership to take advantage of the affirmative action programs. Credit market discrimination appears to be important in construction and especially so for firms owned by African Americans and to a lesser extent for Hispanics.

\section{Conclusion}

The main findings of this paper are that despite the existence of various programs designed to improve the position of women and minorities in construction, little has changed in the last twenty five years. We presented evidence that showed that where race conscious affirmative action programs exist they appear to generate significant improvements. For example, there is evidence that when they are put in place the self-employment rate of minorities rises. We also showed that when these programs are removed or replaced with race-neutral programs the utilization of minorities and women in public construction declines rapidly.

The Croson decision in 1989, however, made it very difficult to maintain affirmative action programs and many were subsequently struck down by the courts. Where they did remain in existence many were watered down to the extent that many only had race-neutral components left. The evidence we have available to us suggests that very rapidly after the race and gender conscious programs were removed the utilization of firms owned by women and minorities collapsed. The position is particularly serious for African-Americans and less so for Hispanics. They have lower business formation rates, lower self-employment rates and earnings than white males. The position of white females, in contrast, appears to have improved, but some of this improvement is likely via 'front' companies where the white female is reported as the owner but the firm is actually run by their white male spouse.

Several recent cases such as Concrete Works, Gross Seed, Sherbrooke Turf, BAGC, Northern Contracting appear to have stemmed, at least temporarily, the judicial tide pushing against race conscious affirmative action programs in contracting. However, such affirmative action programs have not achieved their objectives of improving the position of minority firms in construction, not because they don't work, as it appears that they do, but because they have not been allowed to work by non-minority contractors and by the courts. Discrimination against minorities in general and African-Americans and Hispanics in particular continues to persist in construction. Plus ca change, plus c'est la meme chose. 
Table 1. Participation of Disadvantaged Business Enterprises on Federal construction projects with goals and state construction projects without goals, 2002.

$\begin{array}{lcc} & \text { State funded } & \text { Federal funds } \\ \text { Alabama } & 3.46 \% & 7.23 \% \\ \text { Arizona } & 2.80 \% & 7.22 \% \\ \text { Connecticut } & 6.79 \% & 15.86 \% \\ \text { Delaware } & 3.95 \% & 8.16 \% \\ \text { Florida } & 8.30 \% & 5.59 \% \\ \text { Idaho } & 3.77 \% & 9.81 \% \\ \text { Kansas } & 1.93 \% & 8.26 \% \\ \text { Kentucky } & 3.87 \% & 10.17 \% \\ \text { Michigan } & 5.06 \% & 12.65 \% \\ \text { Minnesota } & 4.42 \% & 6.63 \% \\ \text { Mississippi } & 12.11 \% & 10.68 \% \\ \text { Nebraska } & 3.68 \% & 7.24 \% \\ \text { Nevada } & 1.11 \% & 6.61 \% \\ \text { New Hampshire } & 14.27 \% & 22.11 \% \\ \text { Oregon } & 1.68 \% & 7.88 \% \\ \text { Utah } & 2.57 \% & 5.81 \% \\ \text { Vermont } & 6.31 \% & 12.85 \% \\ \text { Wyoming } & 16.32 \% & 14.40 \% \\ \text { Average } & 5.7 \% & 10.0 \%\end{array}$

Source: Federal Highways Administration 
Table 2a. Summary of MWBE Participation in Contracts Awarded by MnDOT 1996-1999

\begin{tabular}{|c|c|c|c|c|c|c|c|c|c|}
\hline Year & Total Federal \$ & $\begin{array}{l}\text { Minority } \\
\text { men \$ }\end{array}$ & $\%$ & $\begin{array}{l}\text { Minority } \\
\text { Women \$ }\end{array}$ & $\%$ & $\begin{array}{l}\text { Caucasian } \\
\text { Women \$ }\end{array}$ & $\%$ & $\begin{array}{c}\text { Total MWBE } \\
\$ \text { awarded }\end{array}$ & $\%$ \\
\hline FFY96 & $\$ 209,964,333$ & $\$ 3,467,523$ & 1.65 & $\$ 176,480$ & 0.08 & $\$ 20,056,922$ & 9.55 & $\$ 23,700,825$ & 11.29 \\
\hline FFY97 & $\$ 241,031,074$ & $\$ 6,002,497$ & 2.49 & $\$ 108,519$ & 0.05 & $\$ 19,441,750$ & 8.07 & $\$ 25,552,766$ & 10.80 \\
\hline FFY98 & $\$ 285,081,558$ & $\$ 6,589,434$ & 2.31 & $\$ 129,647$ & 0.04 & $\$ 22,515,424$ & 7.89 & $\$ 29,234,500$ & 10.25 \\
\hline FFY99 & $\$ 295,835,471$ & $\$ 841,239$ & 0.28 & $\$ 40,028$ & 0.01 & $\$ 5,761,276$ & 1.95 & $\$ 6,642,543$ & 2.25 \\
\hline
\end{tabular}

\begin{tabular}{|c|c|c|c|c|c|c|c|}
\hline Year & Total Federal \$ & Minority Men \$ & $\%$ & Women \$ & $\%$ & Total MWBE \$ & $\begin{array}{c}\text { Total MWBE } \\
\%\end{array}$ \\
\hline Q1-FFY00 & $\$ 22,099,798.27$ & $\$ 0$ & 0 & $\$ 0$ & 0 & $\$ 0$ & 0 \\
\hline Q2-FFY00 & $\$ 55,219,499.00$ & $\$ 0$ & 0 & $\$ 126,224.00$ & 0.23 & $\$ 126,224.00$ & 0.2 \\
\hline Q3-FFY00 & $\$ 172,252,885.00$ & $\$ 353,805.00$ & 0.21 & $\$ 2,005,974.00$ & 1.16 & $\$ 2,359,779.00$ & 1.4 \\
\hline Q4-FFY00 & $\$ 79,898,976.00$ & $\$ 1,128,366.51$ & 1.41 & $\$ 3,364,234.50$ & 4.21 & $\$ 4,492,601.02$ & 5.6 \\
\hline FFY00 & $\$ 329,471,158.27$ & $\$ 1,482,171.51$ & 0.45 & $\$ 5,496,432.50$ & 1.67 & $\$ 6,978,604.03$ & 2.1 \\
\hline Q1-FFY01 & $\$ 14,184,474.65$ & $\$ 1,003,401.33$ & 7.07 & $\$ 234,880.11$ & 1.66 & $\$ 1,238,281.51$ & 8.7 \\
\hline
\end{tabular}


Table 3. Self-employment rates $1979-2005$ by race and gender

\begin{tabular}{|c|c|c|c|c|c|c|c|c|}
\hline & \multicolumn{4}{|c|}{ All industries } & \multicolumn{4}{|c|}{ Construction industry } \\
\hline & $\begin{array}{l}\text { White } \\
\text { male }\end{array}$ & $\begin{array}{l}\text { White } \\
\text { female }\end{array}$ & Black & Hispanic & $\begin{array}{l}\text { White } \\
\text { male }\end{array}$ & $\begin{array}{l}\text { White } \\
\text { female }\end{array}$ & Black & Hispanic \\
\hline \multicolumn{9}{|c|}{ A) Incorporated } \\
\hline $1979-83$ & 3.6 & 1.0 & 0.3 & 0.8 & 4.8 & 4.9 & 1.1 & 1.2 \\
\hline $1984-88$ & 4.2 & 1.3 & 0.4 & 1.0 & 5.3 & 6.7 & 1.2 & 1.3 \\
\hline 1989-93 & 4.5 & 1.5 & 0.5 & 1.1 & 5.9 & 8.5 & 1.6 & 2.2 \\
\hline 1994-98 & 5.0 & 2.1 & 0.8 & 1.2 & 6.7 & 11.2 & 1.9 & 2.2 \\
\hline 1999-04 & 5.2 & 2.1 & 1.1 & 1.3 & 7.6 & 9.8 & 2.3 & 1.8 \\
\hline \multicolumn{9}{|c|}{ B) Unincorporated } \\
\hline $1979-83$ & 11.5 & 5.6 & 3.2 & 4.7 & 19.4 & 7.4 & 10.0 & 10.9 \\
\hline $1984-88$ & 11.4 & 6.4 & 3.4 & 5.4 & 19.9 & 10.3 & 11.3 & 11.6 \\
\hline $1989-93$ & 11.3 & 6.6 & 3.7 & 5.7 & 21.1 & 12.0 & 14.6 & 12.6 \\
\hline $1994-98$ & 10.4 & 7.2 & 3.7 & 5.2 & 19.6 & 14.3 & 12.2 & 9.8 \\
\hline 1999-04 & 9.4 & 6.6 & 3.9 & 5.2 & 18.9 & 11.5 & 13.2 & 10.4 \\
\hline \multicolumn{9}{|c|}{ C) All Self-employed } \\
\hline $1979-83$ & 15.1 & 6.6 & 3.5 & 5.5 & 24.2 & 12.4 & 11.1 & 12.1 \\
\hline 1984-88 & 15.6 & 7.6 & 3.8 & 6.5 & 25.2 & 17.0 & 12.5 & 12.8 \\
\hline 1989-93 & 15.8 & 8.1 & 4.2 & 6.8 & 27.0 & 20.5 & 16.2 & 14.8 \\
\hline 1994-98 & 15.4 & 9.3 & 4.4 & 6.4 & 26.3 & 25.5 & 14.1 & 12.0 \\
\hline 1999-04 & 14.6 & 8.6 & 4.9 & 6.5 & 26.5 & 21.2 & 15.5 & 12.2 \\
\hline
\end{tabular}

Source: MORG files of the CPS (weighted). For years 1979-1982 the 1970 SIC is used to define industry. 1980 SIC is used until 2002 which is then replaced with the 2000 NAICS 
Table 4. Private Sector Self-employment Probabilities, 1979-2004.

\begin{tabular}{|c|c|c|c|c|c|c|c|}
\hline & $(1)$ & (2) & (3) & (4) & (5) & (6) & (7) \\
\hline & 1979-1991 & $1992-2002$ & 1979-1991 & 1979-1991 & $1992-2004$ & $1992-2004$ & $1992-2004$ \\
\hline & All industries & All industries & Construction & Construction & Construction & Construction & Construction \\
\hline & Self-employed & Self-employed & Self-employed & Incorporated & Self-employed & Unincorporated & Incorporated \\
\hline \multirow[t]{2}{*}{ White Female } & -.0458 & -.0271 & -.1083 & .0029 & -.0492 & -.0689 & .0158 \\
\hline & $(142.24)$ & (66.35) & $(32.95)$ & $(2.25)$ & (13.89) & $(22.26)$ & $(9.53)$ \\
\hline \multirow[t]{2}{*}{ Black } & -.0556 & -.0440 & -.1174 & -.0259 & -.1103 & -.0615 & -.0372 \\
\hline & $(116.14)$ & $(65.57)$ & $(29.46)$ & $(16.37)$ & $(24.43)$ & $(15.23)$ & $(18.22)$ \\
\hline \multirow[t]{2}{*}{ Hispanic } & -.0399 & -.0374 & -.0817 & -.0204 & -.0898 & -.0649 & -.0228 \\
\hline & $(67.40)$ & (52.93) & (17.65) & $(10.26)$ & $(21.12)$ & $(17.56)$ & $(10.84)$ \\
\hline \multirow[t]{2}{*}{ Other races } & -.0256 & $\mathrm{n} / \mathrm{a}$ & -.1192 & -.0160 & $\mathrm{n} / \mathrm{a}$ & $\mathrm{n} / \mathrm{a}$ & $\mathrm{n} / \mathrm{a}$ \\
\hline & (33.69) & & $(17.94)$ & (6.11) & & & \\
\hline \multirow[t]{2}{*}{ Asian } & & -.0060 & & & -.0793 & -.0520 & -.0193 \\
\hline & & (5.86) & & & $(8.74)$ & $(6.41)$ & $(4.88)$ \\
\hline \multirow[t]{2}{*}{ American Indian } & & -.0213 & & & -.0945 & -.0654 & -.0242 \\
\hline & & $(11.70)$ & & & $(10.83)$ & (8.65) & $(5.68)$ \\
\hline \multirow[t]{2}{*}{ Construction } & -.0506 & -.0481 & $\mathrm{n} / \mathrm{a}$ & & $\mathrm{n} / \mathrm{a}$ & $\mathrm{n} / \mathrm{a}$ & $\mathrm{n} / \mathrm{a}$ \\
\hline & $(59.21)$ & $(44.62)$ & & & & & \\
\hline \multirow[t]{2}{*}{ Years of education } & .0101 & No & .0172 & .0084 & No & No & No \\
\hline & $(171.23)$ & & $(41.36)$ & $(49.81)$ & & & \\
\hline Schooling dummies & No & Yes & No & No & Yes & Yes & Yes \\
\hline Year dummies & Yes & Yes & Yes & Yes & Yes & Yes & Yes \\
\hline Industry Dummies & Yes & Yes & No & No & No & No & No \\
\hline State Dummies & Yes & Yes & Yes & Yes & Yes & Yes & Yes \\
\hline $\mathrm{N}$ & $2,808,248$ & $1,994,519$ & 196,951 & 196,951 & 158,939 & 158,939 & 158,939 \\
\hline Pseudo $\mathrm{R}^{2}$ & .2537 & .2210 & .0886 & .1130 & .0718 & -70608 & -33957 \\
\hline Log Likelihood & -819449 & $-609,176$ & $-100,987$ & -36171 & -81564 & .0525 & .0940 \\
\hline
\end{tabular}

Notes: Probit analysis is performed using the dProbit command in STATA on a sample of workers. The percentages reported here are the coefficients from the Probit analysis and indicate the percentage point differences in self-employment rates between the indicated group and Whites. Equations also include age and its square as controls. Self-employment includes both the incorporated and unincorporated. T-statistics in parentheses. Source: Outgoing Rotation Group files of the Current Population Survey, $1979-2004$. 
Table 5. Private Sector Self-employment Construction Industry Dprobits, 2000.

\begin{tabular}{|l|c|c|c|}
\hline & $(1)$ & $(2)$ & $(3)$ \\
\hline & 2000 & 2000 & 2000 \\
\hline White Female & Self-employed & Unincorporated & Incorporated \\
\hline & -.0859 & -.0923 & .0085 \\
\hline Black & $(39.55)$ & $(49.90)$ & $(6.97)$ \\
\hline & -.1064 & -.0693 & -.0305 \\
\hline Hispanic & $(36.95)$ & $(28.02)$ & $(19.27)$ \\
\hline & -.0788 & -.0605 & -.0151 \\
\hline Other races & $(26.14)$ & $(23.72)$ & $(8.67)$ \\
\hline & -.0844 & -.0635 & -.0183 \\
\hline Asian/Pacific Islander & $(31.12)$ & $(27.75)$ & $(11.49)$ \\
\hline & -.0395 & -.0287 & -.0066 \\
\hline American Indian & $(6.06)$ & $(5.14)$ & $(1.87)$ \\
\hline & -.0847 & -.0576 & -.0230 \\
\hline & $(14.77)$ & $(11.84)$ & $(7.02)$ \\
\hline Schooling dummies & & & Yes \\
\hline State Dummies & Yes & Yes & Yes \\
\hline & & Yes & 436,437 \\
\hline $\mathrm{N}$ & 436,437 & 436,437 & .0582 \\
\hline Pseudo R & .0707 & .0572 & -108475 \\
\hline Log Likelihood & -229178 & -242383 & \\
\hline
\end{tabular}

Notes: Probit analysis is performed using the dProbit command in STATA on a sample of workers. The percentages reported here are the coefficients from the Probit analysis and indicate the percentage point differences in self-employment rates between the indicated group and Whites. Equations also include age and its square as controls. Self-employed includes both the incorporated and unincorporated. State dummies include Puerto Rico. All cases with imputed data to one or more variables are deleted.

Source: 2000 Census. T-statistics in parentheses. 
Table 6. Log Self Employment Earnings Equations, 1979-2002

\begin{tabular}{|c|c|c|c|c|c|c|}
\hline & (1) & (2) & (3) & (4) & (5) & (6) \\
\hline & All & All & Construction & Construction & Construction & Construction \\
\hline & $1978-1990$ & 1991-2001 & $1978-1990$ & $1991-2001$ & 1999 & 1999 \\
\hline \multirow[t]{2}{*}{ White female } & -.729 & -.617 & -.835 & -.839 & -.702 & -.513 \\
\hline & $(68.07)$ & $(31.34)$ & $(21.63)$ & $(15.73)$ & $(28.67)$ & $(17.81)$ \\
\hline \multirow[t]{2}{*}{ Black } & -.500 & -.591 & -.428 & -.323 & -.387 & -.350 \\
\hline & $(15.64)$ & $(14.85)$ & (5.73) & $(2.40)$ & (12.09) & (11.03) \\
\hline \multirow[t]{2}{*}{ Hispanic } & -.278 & -.390 & -.252 & -.145 & -.146 & -.118 \\
\hline & $(9.46)$ & $(9.8)$ & (3.96) & (1.38) & $(4.96)$ & $(4.05)$ \\
\hline \multirow[t]{2}{*}{ Other races } & -.328 & -.221 & -.208 & -.180 & -.160 & -.122 \\
\hline & $(8.29)$ & $(3.41)$ & $(1.79)$ & $(0.84)$ & (5.08) & $(4.52)$ \\
\hline \multirow[t]{2}{*}{ Asian/Pacific Islanders } & & & & & .004 & .045 \\
\hline & & & & & $(0.08)$ & $(0.85)$ \\
\hline \multirow[t]{2}{*}{ Native Americans } & & & & & -.397 & -.361 \\
\hline & & & & & $(7.15)$ & $(6.60)$ \\
\hline Occupation dummies (284) & No & No & No & No & No & Yes \\
\hline Education controls (16) & No & Yes & No & Yes & Yes & Yes \\
\hline Year dummies (13) & Yes & Yes & Yes & Yes & No & No \\
\hline State dummies (51) & Yes & Yes & Yes & Yes & Yes & Yes \\
\hline Industry dummies (88) & Yes & Yes & No & No & No & No \\
\hline $\mathrm{N}$ & 82,094 & 55,639 & 12,577 & 8,446 & 64,188 & 64,188 \\
\hline Adjusted $\mathrm{R}^{2}$ & .177 & .128 & .077 & .064 & .064 & .093 \\
\hline
\end{tabular}

Notes: The percents indicate the percent difference in self-employment earnings between the indicated group and Whites. Controls also include age, age squared and a full set of year dummies.

Source: Annual Demographic (March) files of the Current Population Survey for 1979-2002 and 2000 Census. 
Table 7. Determinants of Loan Denial Rates

\begin{tabular}{|c|c|c|c|c|}
\hline & 1993 & 1993 & 1998 & 1998 \\
\hline & (1) & (2) & (3) & (4) \\
\hline Black & $\begin{array}{l}.3132 \\
(7.16)\end{array}$ & $\begin{array}{l}.3338 \\
(6.73)\end{array}$ & $\begin{array}{l}.2923 \\
(4.40)\end{array}$ & $\begin{array}{l}.2471 \\
(3.45)\end{array}$ \\
\hline Asian/Pacific islander & $\begin{array}{l}.1553 \\
(2.84)\end{array}$ & $\begin{array}{l}.1646 \\
(2.84)\end{array}$ & $\begin{array}{l}.1822 \\
(2.66)\end{array}$ & $\begin{array}{l}.1437 \\
(2.01)\end{array}$ \\
\hline Hispanic & $\begin{array}{l}.0522 \\
(1.05)\end{array}$ & $\begin{array}{l}.0113 \\
(0.21)\end{array}$ & $\begin{array}{l}.2528 \\
(3.45)\end{array}$ & $\begin{array}{l}.2446 \\
(3.20)\end{array}$ \\
\hline Female-Owned & $\begin{array}{c}.0373 \\
(1.26)\end{array}$ & $\begin{array}{l}.0305 \\
(0.94)\end{array}$ & $\begin{array}{c}.0581 \\
(1.38)\end{array}$ & $\begin{array}{l}.0411 \\
(0.94)\end{array}$ \\
\hline Black*Construction & & $\begin{array}{l}-.0713 \\
(0.89)\end{array}$ & & $\begin{array}{l}.2537 \\
(1.43)\end{array}$ \\
\hline Asian/Pacific Islander*Construction & & $\begin{array}{l}-.0701 \\
(0.48)\end{array}$ & & $\begin{array}{l}.3306 \\
(1.44)\end{array}$ \\
\hline Hispanic*Construction & & $\begin{array}{l}.1908 \\
(1.51)\end{array}$ & & $\begin{array}{l}.0373 \\
(0.18)\end{array}$ \\
\hline Female-Owned*Construction & & $\begin{array}{l}.0113 \\
(0.21)\end{array}$ & & $\begin{array}{l}.1806 \\
(1.15)\end{array}$ \\
\hline $\mathrm{N}$ & 1986 & 1986 & 962 & 962 \\
\hline Pseudo $\mathrm{R}^{2}$ & .1651 & .1667 & .2633 & .2671 \\
\hline $\mathrm{Chi}^{2}$ & 387.3 & 391.1 & 289.7 & 293.9 \\
\hline Log likelihood & -979.1 & -977.2 & -405.3 & -403.1 \\
\hline
\end{tabular}

Source: Authors' calculations from 1993 and 1998 NSSBF. Notes: controls for 1993 are 8 region dummies, 51 industry dummies, 3 types of organization dummies and 4 creditworthiness variables. Controls for 1998 are 8 region dummies, 37 industry dummies, 43 type of organization dummies, 4 Dunn and Bradstreet credit rating variables and 4 creditworthiness variables.

Reported estimates are derivatives from Probit models, t-statistics are in parentheses) 
Figure 1. Disadvantaged Business Enterprise (DBE) Participation Levels in States That Use DOT's DBE Program But Have no State DBE Program

$\square$ DOT DBE Program (Federal-Aid Highways) $\square$ No DBE Program ( State-Funded Highways)

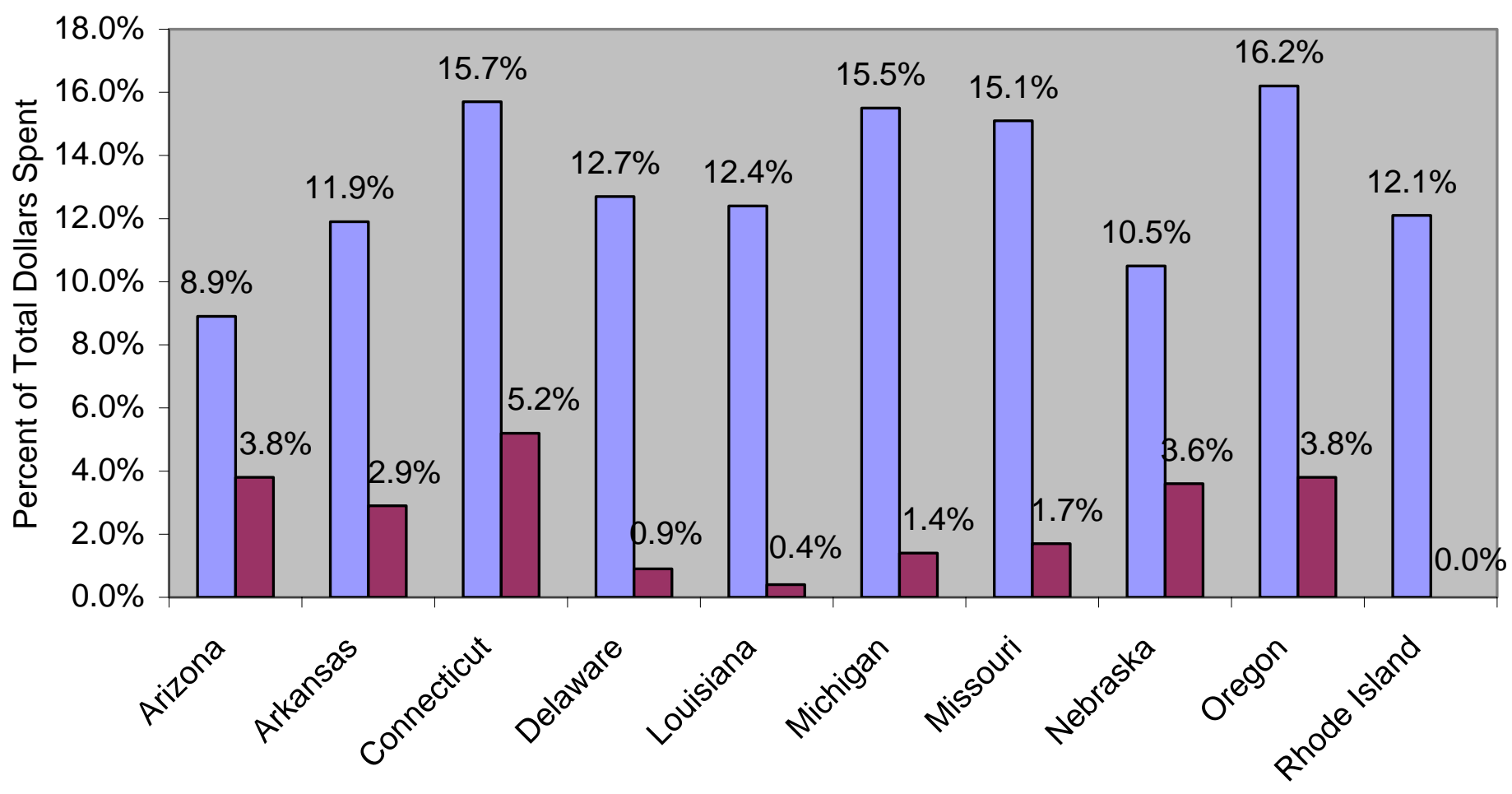

Fiscal Year 1996 
Figure 2: MWBEs' Participation in Louisiana's State-Funded Transportation Contracting, 1992-2000 (Source: GAO's analysis of data from Louisiana's Department of Transportation)

Percentage

50

45

40

35

30

25

20

15

10

0

1992

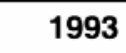

1993

1994

1995

1996

1997

1998

19992000

Year

Contracts awarded

- Dollars awarded 
Figure 3: DBEs' Participation in Federal Transportation Contracting in Minnesota, 1995-2000 (Source: GAO's analysis of data from Minnesota's Department of Transportation).

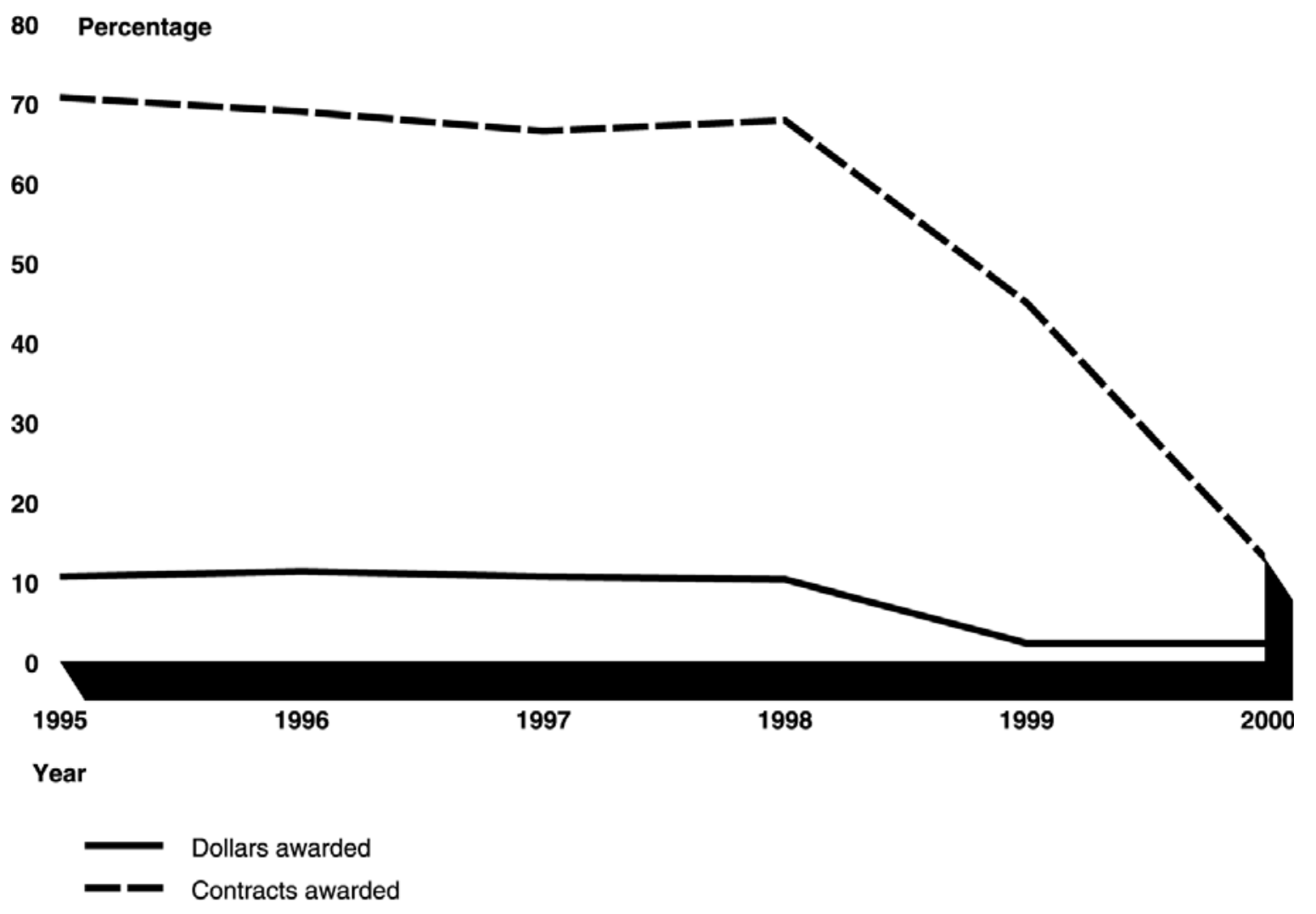




\section{$\underline{\text { References }}$}

Arrow, K.J. (1998), 'What has economics to say about racial discrimination?', Journal of Economic Perspectives, 12(2), pp. 91-100.

Ashenfelter, O. (1972), 'Race discrimination and trade unionism', Journal of Political Economy, Volume 80, Issue 3, Part 1, May-June pp. pp. 435-464.

Blanchflower, D.G., (2000), 'Self-employment in OECD countries', Labour Economics, 7, September, pp. 471-505.

Blanchflower, D.G., (2004), 'Self-employment: more may not be better', Swedish Economic Policy Review, 11(2), Fall, pp.15-74.

Blanchflower, D.G. and A. Bryson (2003), 'Changes over time in union relative wage effects in the UK and the US revisited', International Handbook of Trade Unions, Edward Elgar, edited by John Addison and Claus Schnabel.

Blanchflower, D.G. and A. Bryson (2004), 'What effect do unions have on wages now and would Freeman and Medoff be surprised?', Journal of Labor Research, 25(3), Summer, pp. 383-414 and in What do unions do?: the evidence twenty years later, edited by James T. Bennett and Bruce E. Kaufman, forthcoming.

Blanchflower, P. Levine and D. Zimmerman (1998), 'Discrimination in the small business credit market', National Bureau of Economic Research Working Paper \#W6840, Cambridge, MA.

Blanchflower, P. Levine and D. Zimmerman (2003), 'Discrimination in the small business credit market', Review of Economics and Statistics, November, 85(4), pp. 930-943.

Blanchflower D.G. and A.J. Oswald (2004), 'Wellbeing over time in Britain and the United States', Journal of Public Economics, 88(7-8), pp.1359-1386.

Cavalluzzo, K., L. Cavalluzzo and J. Wolken (2002), 'Competition, small business financing and discrimination: evidence from a new survey', Journal of Business, 75, October, pp.641-679.

Chandra, A. and J. Skinner (2003), 'Geography and racial health disparities,' in Critical perspectives on racial and ethnic differences in health in late life, edited by N. B. Anderson, R.A. Bulatao, and B. Cohen, Panel on race, ethnicity, and health in later life, National Research Council, pp.604-639.

Chay, K.Y. and R. W. Fairlie (1998), 'Minority business set-asides and black self-employment, Working Paper, December.

Cutler, D.M. Glaeser, E.L. and J.L. Vigdor (1999), 'The rise and decline of the American ghetto', Journal of Political Economy, 107(3), pp. 455-506. 
Enchautegui, M.E., M. Fix, P. Loprest, S. von der Lippe, and D. Wissoker (1997), Do MinorityOwned Businesses Get a Fair Share of Government Contracts? Washington, D.C.: Urban Institute.

Fairlie, R. W. (1999), 'The absence of the African-American owned business: an analysis of the dynamics of self-employment', Journal of Labor Economics, 17(1), pp. 80-108.

Fairlie, R.W. and B.D. Meyer (2000), 'Trends in self-employment among white and black men during the twentieth century', Journal of Human Resources, XXXV(4), pp. 643-669.

Feinstein, J.S. M.K. Block and F.C. Nold (1985), 'Asymmetric information and collusive behavior in auction markets', American Economic Review, 75, June, pp. 441-460.

Freeman, R.B (2000), 'Disadvantaged young men and crime' in Youth employment and joblessness in advanced countries, edited by D.G. Blanchflower and R.B. Freeman, University of Chicago Press and NBER.

Fryer, R.G. and S. Levitt (2003), 'The causes and consequences of distinctively black names', NBER Working Paper \#9938.

General Accounting Office (2001), Disadvantaged business enterprises, Report to Congressional Committees, GAO-01-586, June, Washington DC.

Glover, R.W (1977), Minority enterprise in construction, Praeger Publications.

Gupta, S. (2001), 'The effect of bid rigging on prices: a study of the highway construction industry', Review of Industrial Organization, December, 19(4), pp. 453-467

Gupta, S. (2002), 'Competition and collusion in government procurement auction market', Atlantic Economic Journal, 30(1), March, pp. 13-25

Heckman, J., T. Lyons and P. Todd (2000), 'Understanding black-white wage differentials, 19601990,' American Economic Review, 90(2), pp. 344-49.

Hirsch, B.T., and E.J. Schumacher (2004), 'Match bias in wage gap estimates due to earnings imputation', Journal of Labor Economics, Vol. 22, No. 3, July, pp. 689-722.

Holt, C. (2003) 'Strict constitutional scrutiny is not fatal in fact: federal courts uphold affirmative action programs in public contracting,' Labor Law Journal, Winter, 54(4), pp. 248-262.

Ingraham, Allan, T. (2005), 'A test for collusion between a bidder and an auctioneer in sealed-bid auctions', Contributions to Economic Analysis \& Policy, Volume 4, Issue 1, pp. 1-32

Jencks, C., and M. Phillips (1998), 'The black-white test score gap’, Washington DC: The Brookings Institute. 
Kessler, D.P. and L.F. Katz (2001), 'Prevailing Wage Laws and construction labor markets', Industrial and Labor Relations Review, 54(2), January, pp. 259-274.

Marshall, R. (2000), 'Minority and female business development after Croson', University of Texas Working Paper.

Porter, R. H. and D. J. Zona (1993), 'Detection of bid-rigging in procurement auctions,' Journal of Political Economy, 101(3), pp. 518-538.

Smith, J.P. and F.R. Welch (1989), 'Black economic progress after Myrdal', Journal of Economic Literature, 27(2), June, pp.519-64.

U.S. Chamber of Commerce (2005), Access to capital: what funding sources work for you?, U.S. Chamber of Commerce, May, Washington DC.

U.S. Commission on Civil Rights (2005), Federal procurement after Adarand, September, Washington DC.

Ventura, S. and C. Bachrach (2000), 'Non-marital childbearing in the United States, 1940-1999,' National Vital Statistics Reports, 48(16), Hyattsville, MD: National Center for Health Statistics.

Wainwright, J. (2000), Racial discrimination and minority business enterprise: evidence from the 1990 census, Studies in Entrepreneurship Series, New York and London: Garland Publishing. 